\title{
P05.35. What are participants in clinical trials told about placebos? A content analysis of participant information leaflets
}

\author{
F Bishop ${ }^{1}$, A Adams²*, T Kaptchuk ${ }^{3}$, G Lewith ${ }^{1}$ \\ From International Research Congress on Integrative Medicine and Health 2012 \\ Portland, Oregon, USA. 15-18 May 2012
}

\section{Purpose}

To identify what participants in major RCTs in the UK are told about placebos and their effects.

\section{Methods}

The major registry of current clinical trials in the UK (UKCRN) was searched to identify trials conducted in clinical populations using placebo controls. Emails were sent to 182 contact personnel requesting they send their participant information leaflets (PILs) for inclusion in the study. Forty-nine PILs were received; 45 were included in the analysis (4 were ineligible). Qualitative and quantitative techniques of content analysis were used to identify characteristics of the trials, how the placebo and target treatment were explained, the presence or absence of information about possible effects of the target and placebo treatments, and options concerning un-blinding and possible treatments after the trial.

\section{Results}

Placebos and target treatments were described quite differently. In almost every comparison, the target treatments were prioritized over the placebo, from the words in the title to the description of what would happen at the end of the trial. The placebo was described as a scientific tool that would allow efficacy of the target treatment to be determined; the target treatment was described as a treatment that might generate health effects. Placebo treatments were referred to less frequently than target treatments and were significantly less likely to be described as triggering either positive or adverse health effects $(\mathrm{p}<.01)$. A minority of PILs mentioned un-blinding or treatment options after the

${ }^{2}$ Northern Arizona University, Flagstaff, USA

Full list of author information is available at the end of the article trial, and the focus of the latter was primarily on the possibility of continuing with the target treatment.

\section{Conclusion}

Trial participants were poorly informed about the health changes that they might experience if they were allocated to a placebo treatment, and of options that might be available to them after the trial. Different ways of describing placebos to participants, in PILs and in person, should be developed and tested.

\section{Author details}

'University of Southampton, Aldermoor Health Centre, Southampton, England. ${ }^{2}$ Northern Arizona University, Flagstaff, USA. ${ }^{3}$ Harvard University, Cambridge, USA.

Published: 12 June 2012

doi:10.1186/1472-6882-12-S1-P395

Cite this article as: Bishop et al:: P05.35. What are participants in clinical trials told about placebos? A content analysis of participant information leaflets. BMC Complementary and Alternative Medicine 2012 12(Suppl 1): P395.

Submit your next manuscript to BioMed Central and take full advantage of:

- Convenient online submission

- Thorough peer review

- No space constraints or color figure charges

- Immediate publication on acceptance

- Inclusion in PubMed, CAS, Scopus and Google Scholar

- Research which is freely available for redistribution

Submit your manuscript at www.biomedcentral.com/submit

\section{Biomed Central}

(c) 2012 Bishop et al; licensee BioMed Central Ltd. This is an Open Access article distributed under the terms of the Creative Commons Attribution License (http://creativecommons.org/licenses/by/2.0), which permits unrestricted use, distribution, and reproduction in any medium, provided the original work is properly cited. 